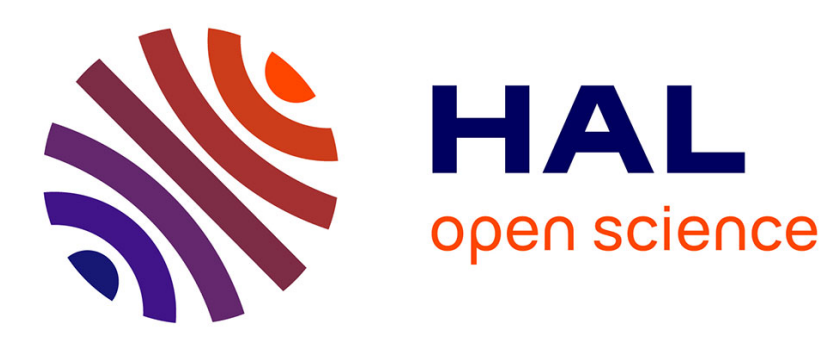

\title{
Elaboration and Characterization of Materials from the LaMnO 3 -BiMnO 3 Binary System
}

Mourad Djahmoum, Omar El Kechaï, Pascal Marchet

\section{To cite this version:}

Mourad Djahmoum, Omar El Kechaï, Pascal Marchet. Elaboration and Characterization of Materials from the LaMnO 3 -BiMnO 3 Binary System. physica status solidi (a), In press, 10.1002/pssa.201900814 . hal-02465803

\section{HAL Id: hal-02465803 \\ https://hal-unilim.archives-ouvertes.fr/hal-02465803}

Submitted on 4 Feb 2020

HAL is a multi-disciplinary open access archive for the deposit and dissemination of scientific research documents, whether they are published or not. The documents may come from teaching and research institutions in France or abroad, or from public or private research centers.
L'archive ouverte pluridisciplinaire HAL, est destinée au dépôt et à la diffusion de documents scientifiques de niveau recherche, publiés ou non, émanant des établissements d'enseignement et de recherche français ou étrangers, des laboratoires publics ou privés. 


\title{
Elaboration and Characterization of Materials from the $\mathrm{LaMnO}_{3}-\mathrm{BiMnO}_{3}$ Binary System
}

\author{
Mourad DJAHMOUM, Omar EL KECHAI, Pascal MARCHET*
}

\begin{abstract}
M. Djahmoum and $\mathrm{P}^{\mathrm{r}} \mathrm{O}$. El Kechaï
Université Mouloud MAMMERI de Tizi-Ouzou,

Tizi-Ouzou 15000, Algérie
\end{abstract}

Dr P. Marchet

IRCER Université de Limoges

UMR 7315 CNRS

12 rue Atlantis

87068 LIMOGES CEDEX France

*pascal.marchet@unilim.fr

\begin{abstract}
The study of the $\mathrm{La}_{(1-\mathrm{x})} \mathrm{Bi}_{\mathrm{x}} \mathrm{MnO}_{3}$ system was carried out using $\mathrm{X}$-ray diffraction and electrical measurements. A continuous solid solution was evidenced for the $\mathrm{LaMnO}_{3}$ rich part of this system (x $\leq 0.6)$. According to the analyses of XRD results, a rhombohedral symmetry $(R \overline{3} c)$ was observed for $\mathrm{x} \leq 0.4$ and a cubic structure for $\mathrm{x}=0.5$. The structural study allowed to determine an increase of the mean perovskite lattice parameter, together with a decrease of the rhombohedral angle up to a cubic symmetry for $\mathrm{x}=0.5$. For $\mathrm{x}>0.6$, the system is no more single-phased. Impedance measurements were carried out for ceramics in a wide frequency range $(100 \mathrm{~Hz}-1 \mathrm{MHz})$, between room temperature and $800^{\circ} \mathrm{C}$. The exponential decrease of the $\mathrm{AC}$ conductivities $\left(\sigma_{\mathrm{AC}}\right)$ and the room temperature values correspond to a semiconducting behavior. DC conductivity measurements $\left(\sigma_{\mathrm{DC}}\right)$ were also performed below room temperature $(25 \mathrm{~K}<\mathrm{T}<300 \mathrm{~K})$. The results evidence for a metal-insulator phase
\end{abstract}


transition. For the exponential part of the $\sigma_{\mathrm{DC}}$ curves, the gap energy is between 0.1 and $0.2 \mathrm{eV}$, confirming the semiconductor behavior of these materials.

KEYWORDS: perovskites, solid solution, phase transitions, semiconductor materials, ceramics.

\section{Introduction}

Perovskite based materials have a long history and are studied now for more than 70 years. Indeed, they present a wide range of interesting physical properties, like dielectric properties, ferroelectricity / piezoelectricity, magnetic properties, superconductivity, metallic conductivity... ${ }^{[1-2]}$ Such a large range of properties allows a large field of applications such as piezoelectric transducers, magnetic recording heads, energy storage, cathode materials for solid oxide fuel cells (SOFC), catalyzers for oxydo-reduction (car motors)... In 1994, the discovery of intrinsic giant magnetoresistance phenomena in $\mathrm{La}_{1-\mathrm{x}} \mathrm{A}_{\mathrm{x}} \mathrm{MnO}_{3}$ compounds induced a new field of interest for perovskite compounds because of their potential technological applications. ${ }^{[3-5]}$ Indeed, such materials exhibit fascinating physical phenomena such as colossal magnetoresistance, metal-insulator phase transitions, charge ordering and orbital ordering. Such properties result from an interplay between magnetic, transport and structural properties.${ }^{[4]}$ At the present time, one of the most studied

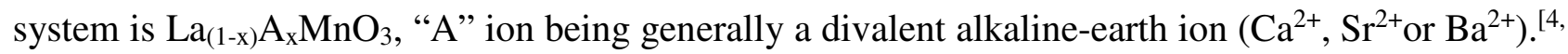
6] Substituting around $30 \%(\mathrm{x}=0.3)$ in the $\mathrm{La}_{(1-\mathrm{x})} \mathrm{Ca}_{\mathrm{x}} \mathrm{MnO}_{3}$ and $\mathrm{La}_{(1-\mathrm{x})} \mathrm{Sr}_{\mathrm{x}} \mathrm{MnO}_{3}$ systems led to a quite complex phase diagram and allowed to obtain a change from paramagnetic-insulating $\mathrm{LaMnO}_{3}$ pure compound to ferromagnetic-metallic behavior at room temperature. More recently, these studies were extended to other lanthanide-based compounds. ${ }^{[7]}$ However, a more recent study on $\mathrm{La}_{(1-\mathrm{x})} \mathrm{Mg}_{\mathrm{x}} \mathrm{MnO}_{3}$ $(\mathrm{x}=0.10,0.25,0.50)$ reported for a rhombohedral $R \overline{3} c$ symmetry and a semiconducting behavior. ${ }^{[8]}$ Stoichiometric $\mathrm{LaMnO}_{3}$ can be prepared by different routes and is paramagnetic and insulating at room temperature $\left(\mathrm{T}_{\mathrm{N}} \approx 145 \mathrm{~K}\right)$, with an orthorhombic symmetry (space group Pnma). ${ }^{[9,10]}$ In the literature, the physical properties of $\mathrm{LaMnO}_{3}$ are reported as very sensitive to parameters such as temperature, pressure, chemical substitution or the route used for elaboration. When heated in air 
atmosphere, oxidation of manganese occurs, from $\mathrm{Mn}^{\mathrm{III}}$ to $\mathrm{Mn}^{\mathrm{IV}}$, leading to a non-stoichiometric $\mathrm{LaMnO}_{3+\delta}$ compound with rhombohedral symmetry (space group $R \overline{3} c$ ). ${ }^{[11-13]}$ In a similar way, a change of manganese oxidation state can occur for $\mathrm{La}_{1-\mathrm{t}} \mathrm{MnO}_{3+\delta}$ compounds, also leading to a rhombohedral distortion. ${ }^{[11-13]}$

In 2002, it was suggested that the study of the $\mathrm{LaMnO}_{3}-\mathrm{BiMnO}_{3}$ system would be interesting. ${ }^{[14]}$ Indeed, the substitution of lanthanum by alkaline-earth ions induces the transition from antiferromagnetic to ferromagnetic metallic state. On the contrary, this substitution in $\mathrm{BiMnO}_{3}$-based manganites destroys the ferromagnetic order, leading to a spin glass behavior. ${ }^{[14]}$ Both $\mathrm{LaMnO}_{3}$ and $\mathrm{BiMnO}_{3}$ compounds, which are end-members of this solid solution, present a perovskite structure but their physical properties are different. Indeed, $\mathrm{BiMnO}_{3}$ can only be obtained by high-pressure synthesis: $\mathrm{BiMnO}_{3}$ perovskite compound decomposes around $600{ }^{\circ} \mathrm{C}$ into $\mathrm{Bi}_{2} \mathrm{O}_{3}$ and $\mathrm{Bi}_{2} \mathrm{Mn}_{4} \mathrm{O}_{9}{ }^{[15]}$ $\mathrm{BiMnO}_{3}$ is an insulating ferromagnetic compound at low temperature $\left(\mathrm{T}_{\mathrm{C}}=102 \mathrm{~K}\right)$ and presents at room temperature a monoclinic structure with space group $C 2 / c .^{[16,17]}$

Now, there are only a few reports devoted to the $\mathrm{LaMnO}_{3}-\mathrm{BiMnO}_{3}$ system. The first study evidenced for a solid solution $\mathrm{La}_{(1-\mathrm{x})} \mathrm{Bi}_{\mathrm{x}} \mathrm{MnO}_{3}$ up to $\mathrm{x}<0.65$. For samples prepared in air, the symmetry is rhombohedral up to $\mathrm{x}=0.4$, while higher $\mathrm{Bi}$ content leads to tetragonal symmetry. ${ }^{[14]}$ The solid-solution limit was later confirmed around $\mathrm{x}=0.6$, all the compositions being rhombohedral. ${ }^{[18]}$ More recently, the solid solution limit was reported for $\mathrm{x}=0.7$, the symmetry changing from orthorhombic $(\mathrm{x}<0.35)$ to pseudo cubic and then to $\mathrm{BiMnO}_{3}$ tetragonal type for $\mathrm{x} \geq$ 0.5. But this study didn't report of the X-ray diffraction patterns or structural arguments. ${ }^{[19,20]}$ The $\mathrm{La}_{0.94} \mathrm{Bi}_{0.06} \mathrm{MnO}_{3}$ composition was later described as orthorhombic, but the reported X-ray diffraction pattern corresponds more to a rhombohedral symmetry. ${ }^{[21]}$ In addition, a more recent paper reported a change from orthorhombic to cubic symmetry around $\mathrm{x}=0.3{ }^{[22]}$ The structural evolution of the $\mathrm{La}(1-\mathrm{x}) \mathrm{Bi}_{\mathrm{x}} \mathrm{MnO}_{3}$ solid-solution and the upper solubility limit remain thus as unclear.

Concerning the electrical properties, only three papers report electrical properties. Metalinsulator transitions and large magnetoresistance effects were observed for low Bi-doping levels $(\mathrm{x}<$ 
$0.4)$, while insulating behavior was reported for higher doping levels $(x \geq 0.4) .{ }^{[18]}$ Nevertheless, the exponential decrease of the resistivity as a function of temperature and the values of resistivity at room temperature (1 to $10 \Omega . \mathrm{m}$ ) seem to correspond more to a semiconducting behavior. ${ }^{[18]}$ Furthermore, the second paper including electrical properties reported metal conduction for $\mathrm{x}>0.1$, but the corresponding curves evidence for a decrease of resistivity as a function of temperature. ${ }^{[19,20]}$ As a consequence, the electrical properties remain unclear for this system.

To sum up, a $\mathrm{La}(1-\mathrm{-x}) \mathrm{Bi}_{\mathrm{x}} \mathrm{MnO}_{3}$ solid solution exists for the $\mathrm{LaMnO}_{3}$ rich part of the system, but there are discrepancies concerning the upper solubility limit. In addition, there is no agreement concerning the crystalline symmetry and its evolution with Bi-content. Indeed, to our knowledge, structural refinements were never reported for this system. Moreover, there are only few reports concerning the electrical properties of $\mathrm{Bi}$-substituted $\mathrm{LaMnO}_{3}$ and the corresponding results present some discrepancies. Therefore, the aim of the present study is the investigation of: (i) the structural evolution of the $\mathrm{La}_{(1-\mathrm{x})} \mathrm{Bi}_{\mathrm{x}} \mathrm{MnO}_{3}$ solid solution and (ii) of the electrical properties for the corresponding compositions.

\section{Materials and methods}

The $\mathrm{La}_{(1-\mathrm{x})} \mathrm{Bi}_{\mathrm{x}} \mathrm{MnO}_{3}$ compounds $(\mathrm{x}=0$ to $\mathrm{x}=1$ ) were elaborated by classical solid-state reaction using $\mathrm{Mn}_{2} \mathrm{O}_{3}$ (Aldrich, 99.8\%), $\mathrm{Bi}_{2} \mathrm{O}_{3}$ (Interchim, 99.075\%), and $\mathrm{La}_{2} \mathrm{O}_{3}$ (Alfa Aesar, 99.998\%) as raw materials. After weighing in stoichiometric amounts, the mix was homogenized in an agate mortar. The powders were then calcined in air in alumina crucibles for 10 to 12 hours between 900 and $1000{ }^{\circ} \mathrm{C}$, using a $10^{\circ} \mathrm{C} / \mathrm{min}$ heating rate and natural cooling of the furnace. After synthesis, the powders were crushed and studied by X-ray diffraction at room temperature using a $\theta / 2 \theta$ diffractometer (Bruker D8 advance, $\mathrm{Cu} \mathrm{K} \alpha 1$ radiation, $\lambda=1.5406 \AA$ ) for $2 \theta$ angles ranging from 10 to $120^{\circ}$. The structure and lattice parameters of the observed phases were calculated using Rietveld refinement with the Jana 2006 software. ${ }^{[23]}$ 
The powders were then pressed into cylindrical pellets $(\phi=10 \mathrm{~mm}, \mathrm{e}=1 \mathrm{~mm}, \mathrm{P} \approx 250 \mathrm{MPa})$ and sintered between 900 and $1100{ }^{\circ} \mathrm{C}$ for 10 hours, depending on the composition. The relative densities of the pellets were determined by geometrical method to be around $90-95 \%$ of theoretical density. The pellets were then electroded using silver paint before study of their alternative current (AC) electrical properties by impedance measurements (100 Hz - $1 \mathrm{MHz}$, Agilent 4294A), between room temperature and $800{ }^{\circ} \mathrm{C}$. The measured complex admittance $\mathrm{Y}=1 / \mathrm{Z}$ is thus such as $\mathrm{Y}=\mathrm{G}+$ $\mathrm{jB}$. This measurement allows a calculation of the approximate values of the AC conductivity $\left(\sigma_{\mathrm{AC}}\right)$ : $\sigma_{\mathrm{AC}}=\mathrm{G} .(\mathrm{t} / \mathrm{S})$, $\mathrm{t}$ being the thickness of the measured sample and $\mathrm{S}$ its cross section.

For the $\mathrm{LaMnO}_{3}$ rich part of the solid solution $(\mathrm{x}=0$ to $\mathrm{x}=0.6)$, bar-shaped samples were cut in the cylindrical pellets, with dimensions typically around $1 \mathrm{~mm} \times 1 \mathrm{~mm}$ x 8-10 $\mathrm{mm}$. Then a fourpoint measurement method was used in order to determine the thermal evolution of resistivity below room temperature. Their direct current (DC) electrical properties were studied between 25 and $300 \mathrm{~K}$ using a closed-cycle helium cryostat (Leybold ROK 10-300 and cryogenerator RW2). A constant current source and a digital multimeter were used to determine the current - voltage characteristics at each selected temperature.

\section{Results and discussion}

\subsection{Structural evolution for the $\mathrm{La}(1-\mathrm{x}) \mathrm{Bi}_{\mathrm{x}} \mathrm{MnO} \mathrm{O}_{3}$ solid solution}

The X-ray diffraction patterns $(\mathrm{x}=0$ to $\mathrm{x}=1)$ are represented figure 1 . The solid solution is not continuous: a single-phase perovskite compound is observed from pure $\mathrm{LaMnO}_{3}$ up to $\mathrm{x}=0.6$. From $\mathrm{x}=0.7$ to $\mathrm{x}=0.8$, a perovskite compound is present together with $\mathrm{Bi}_{2} \mathrm{Mn}_{4} \mathrm{O}_{9}$ and $\mathrm{Bi}_{2} \mathrm{O}_{3}$. For $\mathrm{x}$ $\geq 0.8$, the perovskite compound disappears and only $\mathrm{Bi}_{2} \mathrm{Mn}_{4} \mathrm{O}_{9}$ and $\mathrm{Bi}_{2} \mathrm{O}_{3}$ are observed. Therefore, the limit of the solid solution can be estimated to correspond to $\mathrm{x}=0.6$, in agreement with previous results. ${ }^{[14,18]}$ Indeed, perovskite $\mathrm{BiMnO}_{3}$ can only be synthesized under pressure and decomposes around $600^{\circ} \mathrm{C}$ into $\mathrm{Bi}_{2} \mathrm{O}_{3}$ and $\mathrm{Bi}_{2} \mathrm{Mn}_{4} \mathrm{O}_{9} .{ }^{[15]}$ Logically, the same decomposition occurs for the $\mathrm{BiMnO}_{3}$-rich compositions of this system. 
However, the structural evolution does not correspond to the reported one. In our case, a rhombohedral symmetry ( $R \overline{3} c$ space group) is observed up to $\mathrm{x}=0.5$. For $\mathrm{x}=0.6$, the symmetry is difficult to determine but seems to be orthorhombic. Troyantchuk et al. reported an evolution from rhombohedral (up to $\mathrm{x}=0.4$ ) to tetragonal. ${ }^{[14]}$ Zhao et al. reported a rhombohedral symmetry up to $\mathrm{x}$ $=0.60 \cdot{ }^{[18]}$ Ogawa et al. observed an evolution from orthorhombic to pseudo-cubic $(\mathrm{x}=0.4)$ and then tetragonal symmetry $(\mathrm{x}=0.5-0.7),{ }^{[19,20]}$ while Paul Joseph et al reported an orthorhombic symmetry from $x=0$ to $x=0.2$, and a cubic structure for $x=0.3$ to $x=0.5 .{ }^{[22]}$ Logically, the symmetry of the $\mathrm{La}_{(1-\mathrm{x})} \mathrm{Bi}_{\mathrm{x}} \mathrm{MnO}_{3}$ compounds depends of their thermal history, like for pure $\mathrm{LaMnO}_{3} .^{[24,25]}$ But our observations correspond more to those of Zhao, who only reported qualitative considerations for this system, without any structural calculation. ${ }^{[18]}$

Therefore, the lattice parameters, rhombohedral angle and cell volume were determined by Rietveld refinement for the continuous part of the solid solution, using the $R \overline{3} c$ space group in hexagonal setting. The results of the refinement are reported table 1 . An example of the result of Rietveld refinement for $\mathrm{x}=0$ is represented figure 2 . Since the $R \overline{3} c$ space group in hexagonal setting corresponds to a multiple cell, the pseudo-cubic parameters corresponding to a distorted primitive perovskite cell were calculated using the following relationships:

$$
\mathrm{a}_{\mathrm{h}}=2 \mathrm{a}_{\mathrm{p}} \cdot \sin \left(\frac{\alpha_{p}}{2}\right) \quad \mathrm{c}_{\mathrm{h}}=6 \mathrm{a}_{\mathrm{p}} \cdot \sqrt{1-\frac{4}{3} \sin ^{2}\left(\frac{\alpha_{p}}{2}\right)}
$$

Where $a_{h}$ and $c_{h}$ are hexagonal lattice parameters, $a_{p}$ is the pseudo-cubic lattice parameter and $\alpha_{p}$ the rhombohedral distortion angle of the pseudo-cubic lattice ( $\alpha_{p}$ would be $90^{\circ}$ for a perfectly cubic cell). Logically, the "a" pseudo-cubic parameter increases with the increasing bismuth content (figure 3). These results agree well with the ionic radius of twelve coordinated $\mathrm{Bi}^{3+}$ ion $(1.38-1.40 \AA)$ which is higher than the one of $\mathrm{La}^{3+}$ ion $(1.32 \AA) .{ }^{[26]}$ The results also evidence for a decrease of the rhombohedral angle from $\approx 90.5^{\circ}(\mathrm{x}=0)$ to $90^{\circ}$ for $\mathrm{x}=0.5$. This last value indicates a cubic symmetry for $\mathrm{x}=0.5$. The refinement in $R \overline{3} c$ space group allowed obtaining low values of reliability parameters $(\mathrm{Gof} \approx 1.2 \%, \mathrm{Rp}=5,35 \%, \mathrm{Rwp}=6.83 \%$, Table 1$) .{ }^{[27]}$ These values indicate very satisfactory 
structural refinements for X-ray diffraction patterns, testifying for the rhombohedral symmetry close to $\mathrm{LaMnO}_{3}$ and its evolution toward cubic symmetry with increasing $\mathrm{x}$ values.

\subsection{Electrical properties}

For the continuous part of the solid solution $(\mathrm{x}=0$ to $\mathrm{x}=0.6)$, the AC electrical properties (admittance modulus $|\mathrm{Y}|$ and phase angle $\theta$ ) were determined up to $800{ }^{\circ} \mathrm{C}$ (figure 4 ). The admittance modulus is between $7.10^{-3}$ and $12 \mathrm{~S}$ at room temperature, together with a negative phase angle close to $0^{\circ}$. This value of the phase angle indicates a conductor or a semiconducting material at room temperature. Indeed, phase angle would be close to $90^{\circ}$ for an insulating (dielectric) material. The conductivity values $\sigma_{\mathrm{AC}}$ at room temperature $\left(20^{\circ} \mathrm{C}, 1 \mathrm{kHz}\right)$ calculated from the admittance modulus are between $9.10^{-1}$ and $10^{-7} \mathrm{~S} . \mathrm{m}^{-1}$. Therefore, these materials appear more as semiconducting materials $\left(10^{-8} \mathrm{~S} . \mathrm{m}^{-1} \leq \sigma \leq 10^{2} \mathrm{~S} . \mathrm{m}^{-1}\right)$ than insulating $\left(\sigma \leq 10^{-12} \mathrm{~S} . \mathrm{m}^{-1}\right) .{ }^{[28]}$

In addition, the $\mathrm{AC}$ conductivity values at room temperature confirm the structural results (table 2). For the continuous part of the solid solution, the conductivities does not change significantly. Except for $\mathrm{x}=0\left(\sigma_{\mathrm{AC}}=6.510^{-4} \mathrm{~S} . \mathrm{m}^{-1}\right)$ for which the value does not depend on frequency, the other $\sigma_{\mathrm{AC}}$ values fluctuate between $6.610^{-3} \mathrm{~S} \cdot \mathrm{m}^{-1}$ and $\approx 1 \mathrm{~S} \cdot \mathrm{m}^{-1}(0.1 \leq \mathrm{x} \leq 0.6)$. Then, for the two-phase range $(x>0.6)$, the obtained value are three orders of magnitude lower, around $10^{-}$ ${ }^{6}-10^{-7} \mathrm{~S} . \mathrm{m}^{-1}$. These values confirm that the samples containing more than $60 \% \mathrm{Bi}(\mathrm{x}>0.6)$ have a different behavior, in agreement with their two-phase character. Moreover, for the continuous part of the solid solution $(0 \leq x \leq 0.6)$, the plot of $\log (Z)$ as a function of $1 / T$ gives access to an approximate value of the gap energy around $0.1-0.2 \mathrm{eV}$ (this calculation is based on the admittance results of figure 4 and is not represented here).

In order to confirm these values, and to search for metal-insulating phase transitions, the electrical behavior was studied below room temperature $(25 \mathrm{~K}-300 \mathrm{~K})$ by four points DC measurements. The samples of $\mathrm{La}_{(1-\mathrm{x})} \mathrm{Bi}_{x} \mathrm{MnO}_{3}(0 \leq \mathrm{x} \leq 0.6)$ were cut in the form of parallelepiped bars in order to be able to calculate their resistivity. The results of these measurements are represented 
figure 5. For all samples, the resistivity increases first with the temperature, reaches a maximum and then decreases. These phenomena corresponds well to a metal-insulator phase transition, as previously reported for $\mathrm{La}_{1-x} \mathrm{~A}^{2+}{ }_{x} \mathrm{MnO}_{3},{ }^{[3-6]}$ or for the $\mathrm{La}_{(1-\mathrm{x})} \mathrm{Bi}_{\mathrm{x}} \mathrm{MnO}_{3}$ system close to $\mathrm{LaMnO}_{3} .{ }^{[18,}$ 19] For $\mathrm{x}=0$, the temperature of the maximum is $240 \mathrm{~K}$. Compared to previously published results, this value confirms that this samples in non-stoichiometric, with a $\mathrm{Mn}^{4+}$ content around $30 \% .{ }^{[24]}$

A similar maximum is also observed for $\mathrm{x}=0.1$ and $\mathrm{x}=0.2$. However, for the low temperature part, the slope of the curve is high for $\mathrm{x}=0-0.2$, while the curves appear more "flat" for $\mathrm{x}=0.3-$ 0.6 (figure 5). In contrast, all the curves present a similar exponential decrease for the high temperature part, which corresponds well to a semiconductor behavior.

For the exponential part of the curves of figure 5, the values of the resistivity extracted from the current-voltage (I-V) measurements allowed to plot the $\ln (\sigma)$ as a function of 1/T relationships (figure 6). Using these curves, the values of the activation energy $E_{a}$ were calculated for the singlephase perovskite compositions $\mathrm{x}=0$ to 0.6 (figure 6) using the relationship $\sigma_{\mathrm{DC}}=\sigma_{0} \mathrm{e}^{\left(\frac{-\mathrm{Ea}_{\mathrm{a}}}{2 \mathrm{kT}}\right)}, \sigma_{\mathrm{DC}}$ being the DC conductivity, $\mathrm{E}_{\mathrm{a}}$ the bandgap energy, $\mathrm{k}$ the Boltzmann constant and $\mathrm{T}$ the temperature. The results correspond to $\mathrm{E}_{\mathrm{a}}$ values around $0.2 \mathrm{eV}$ for $\mathrm{LaMnO}_{3}$ and $0.3 \mathrm{eV}$ for the other compositions. They present only little change with composition. It should be noted that these values are lower than the band gap reported for "pure" $\mathrm{LaMnO}_{3}(\approx 1 \mathrm{eV}),{ }^{[29,30]}$ However, these values correspond well to the estimated one in the same system $(0.05-0.34 \mathrm{eV}) .^{[20]}$

\section{Conclusion}

We have characterized the physicochemical properties of $\mathrm{La}_{(1-\mathrm{x})} \mathrm{Bi}_{\mathrm{x}} \mathrm{MnO}_{3}(\mathrm{x}=0.1$ to 1 ) ceramics prepared by conventional solid state synthesis. The study of lanthanum substitution by bismuth confirms the existence of a continuous solid solution for the lanthanum-rich part of this system $(0 \leq$ $\mathrm{x} \leq$ 0.6). According to the results reported in the literature, the compositions rich in bismuth are biphasic $(x>0.6)$. For this solid solution, the substitution of lanthanum by bismuth implies a decrease of the rhombohedral distortion of $\mathrm{LaMnO}_{3}$ and leads to a cubic symmetry for $\mathrm{x}=0.5$. The study of 
AC electrical properties reveals a semi-conducting behavior, the substitution of lanthanum by bismuth resulting in a decrease of the conductivity at room temperature. DC measurements performed from 25 to $300 \mathrm{~K}$ confirm the occurrence of a phase transition, associated to metal-insulating phase transition. However, the behavior of the insulating phase corresponds to an exponential decrease of the conductivity with increasing temperature, which means a semiconductor behavior. For the semiconductor part of the resistivity curves, the gap energy was determined to be around $0.1-0.2$ $\mathrm{eV}$, which is lower than the value reported for "pure" $\mathrm{LaMnO}_{3}(\approx 1 \mathrm{eV}) .{ }^{[29]}$ 


\section{References}

[1] A.S. Bhalla, R. Guo, R. Roy, Mat. Res. Innovat. 2000, 4, 3

[2] B. Raveau, Prog. Solid State Chem. 2007, 35171

[3] R. Mahesh, R. Mahendiran, A.K. Raychaudhuri, C.N.R. Rao, J. Solid State Chem. 1995, 114, 297

[4] R. Von Helmolt, J. Wecker, K. Samwer, L. Haupt, K. Barner, J. Appl. Phys. 1994,76, 6925

[5] A. Maignan, C. Simon, V. Caignaert, B. Raveau, Solid State Commun. 1995, 96, 623

[6] R. Mahendiran, S. K. Tiwary, A. K. Raychaudhuri, T. V. Ramakrishnan, R. Mahesh, N. Rangavittal, C. N. R. Rao, Phys. Rev. B, 1996, 53, 3348

[7] C. Autret, C. Martin, M. Hervieu, A. Maignan, B. Raveaa, G. Andre, F. Bouree, Z. Jirak, J. Magn. Magn. Mater. 2004, 270, 194

[8] G. I. Supelanoa, A. J. Baron-Gonzaleza, A. S. Santosa, C. Ortiz, J. A. Mejia Gomez, C. A. Parra Vargas, J. Mater. Res. Technol. 2018, 7, 77

[9] P. Norby, I. G. Krogh Andersen, E. Krogh Andersen, J. Solid State Chem. 1995, 119, 191

[10] J. Rodriguez-Carvajal, M. Hennion, F. Moussa, A. H. Moudden, L. Pinsard, A. Revcolevschi, Phys. Rev. B, 1998, 57, 3189

[11] N. Sakai, H. Fjellvag, Acta Chem. Scand. 1996, 50, 580

[12] B. C. Hauback, H. Fjellvag, N. Sakai, J. Solid State Chem. 1996, 124, 43

[13] N. Sakai, H. Fjellvag, B Lebech, Acta Chem. Scand. 1997, 51, 904

[14] I. O. Troyanchuk, O. S. Mantytskaja, H. Szymczak, M. Yu. Shvedun, Low Temp. Phys. 2002, 28,569

[15] H. Faqir, H. Chiba, M. Kikuchi, Y. Syono, M. Mansori, P. Satre, A. Sebaoun, J. Solid State Chem. 1999, 142, 113

[16] A. A. Belik, S. Iikubo, T. Yokosawa, K. Kodama, N. Igawa, S. Shamoto, M. Azuma, M. Takano, K. Kimoto, Y. Matsui, E. Takayama-Muromachi, J. Am. Chem. Soc. 2007, 129, 971.

[17] P. Toulemonde, P. Bordet, P. Bouvier, J. Kreisel, Phys. Rev. B, 2014, 89, 224107 
[18] Y.D. Zhao, J. Park, R.-J. Jung, H.-J. Noh, S.-J. Oh, J. Magn. Magn. Mater. 2004, 280, 404

[19] T. Ogawa, A. Sandhub, M. Chibaa, H. Takeuchia, Y. Koizumi, J. Magn. Magn. Mater. 2005, $290-291,933$

[20] T. Ogawa, H. Shindo, H. Takeuchi, Y. Koizumi, Jpn. J. Appl. Phys. 2006, 45, 8666

[21] T. Izgi, V.S.Kolat, N.Bayri, H.Gencer, S.Atalay, J. Magn. Magn. Mater. 2014, 372, 112

[22] D. Paul Joseph, J.W. Lin, N. PavanKumar, W.C. Chen, J.G.Lin, J. Magn. Magn. Mater. 2016, 418,68

[23] V. Petricek, M. Dusek, L. Palatinus, Z. Kristallogr. 2014, 229, 345

[24] M. Verelst, N. Rangavittal, C.N.R. Rao, A. Rousset, J. Solid State Chem. 1993, 104, 74

[25] A. Arulraj, R. Mahesh, G. N. Subbanna, R. Mahendiran, A. K. Raychaudhuri, C. N. R. Rao, J. Solid State Chem. 1996, 127, 87

[26] R.D. Shannon, Acta Crystallogr. 1976, A32, 751

[27] W. J. Kuen, L.K. Pah, A. H. Shaari, C. S. Kien, N. S. Wei and A. Gan Han Ming, Pertanika J. Sci. \& Technol. 2012, 20, 81

[28] A.J. Moulson, J.M. Herbert, Electroceramics, materials properties applications, Chapman and Hall, 1990, p. 26

[29] M. Shaterian, M. Enhessari, D. Rabbani, M. Asghari, M. Salavati-Niasari, Appl. Surf. Sci. 2014, 318,213

[30] S. Gong, B. Liu, Phys. Lett. A 2011, 375, 1477 


\section{Figure caption}

Figure 1: X-ray diffraction patterns for the $\mathrm{La}_{(1-\mathrm{x})} \mathrm{Bi}_{\mathrm{x}} \mathrm{MnO}_{3}$ system ( $\mathrm{x}=0$ to 1$)$

Figure 2: Result of the refinement of $\mathrm{LaMnO}_{3}$ composition $(x=0)$ using a rhombohedral $R \overline{3} c$ space group.

Figure 3: Evolution of the " $a$ " lattice parameter of the rhombohedral cell and of the " $\alpha$ " rhombohedral angle as a function of composition for the continuous part of the $\mathrm{La}_{(1-\mathrm{x})} \mathrm{Bi}_{\mathrm{x}} \mathrm{MnO}_{3}$ solid solution.

Figure 4: Results of AC measurements above room temperature: (A) Evolution of the admittance modulus $|\mathrm{Y}|$ and $(\mathrm{B})$ of the phase angle as a function of temperature for the single-phases perovskite compositions ( $\mathrm{x}=0$ to $\mathrm{x}=0.6$ ) of the $\mathrm{La}(1-\mathrm{x}) \mathrm{Bi}_{\mathrm{x}} \mathrm{MnO}_{3}$ solid solution.

Figure 5: Evolution of the DC resistivity as a function of temperature for the single-phases perovskite compositions of the $\mathrm{La}_{(1-\mathrm{x})} \mathrm{Bi}_{\mathrm{x}} \mathrm{MnO}_{3}$ solid solution $(\mathrm{x}=0$ to $\mathrm{x}=0.6)$.

Figure 6: $\operatorname{Ln}(\sigma)$ as a function of $1 / \mathrm{T}$ extracted from the DC resistivity curves for the $\mathrm{La}_{(1-\mathrm{x})} \mathrm{Bi}_{\mathrm{x}} \mathrm{MnO}_{3}$ solid solution $(\mathrm{x}=0$ to $\mathrm{x}=0.6)$.

\section{Table caption}

Table 1: Structural parameters and reliability factors obtained after Rietveld refinement of $\mathrm{La}_{(1-}$ ${ }_{\mathrm{x})} \mathrm{Bi}_{\mathrm{x}} \mathrm{MnO}_{3} \mathrm{X}$-ray diffraction patterns

Table 2: conductivity values $\left(\sigma_{\mathrm{AC}}\right)$ at room temperature $\left(20^{\circ} \mathrm{C}\right)$ extracted from the admittance measurements 


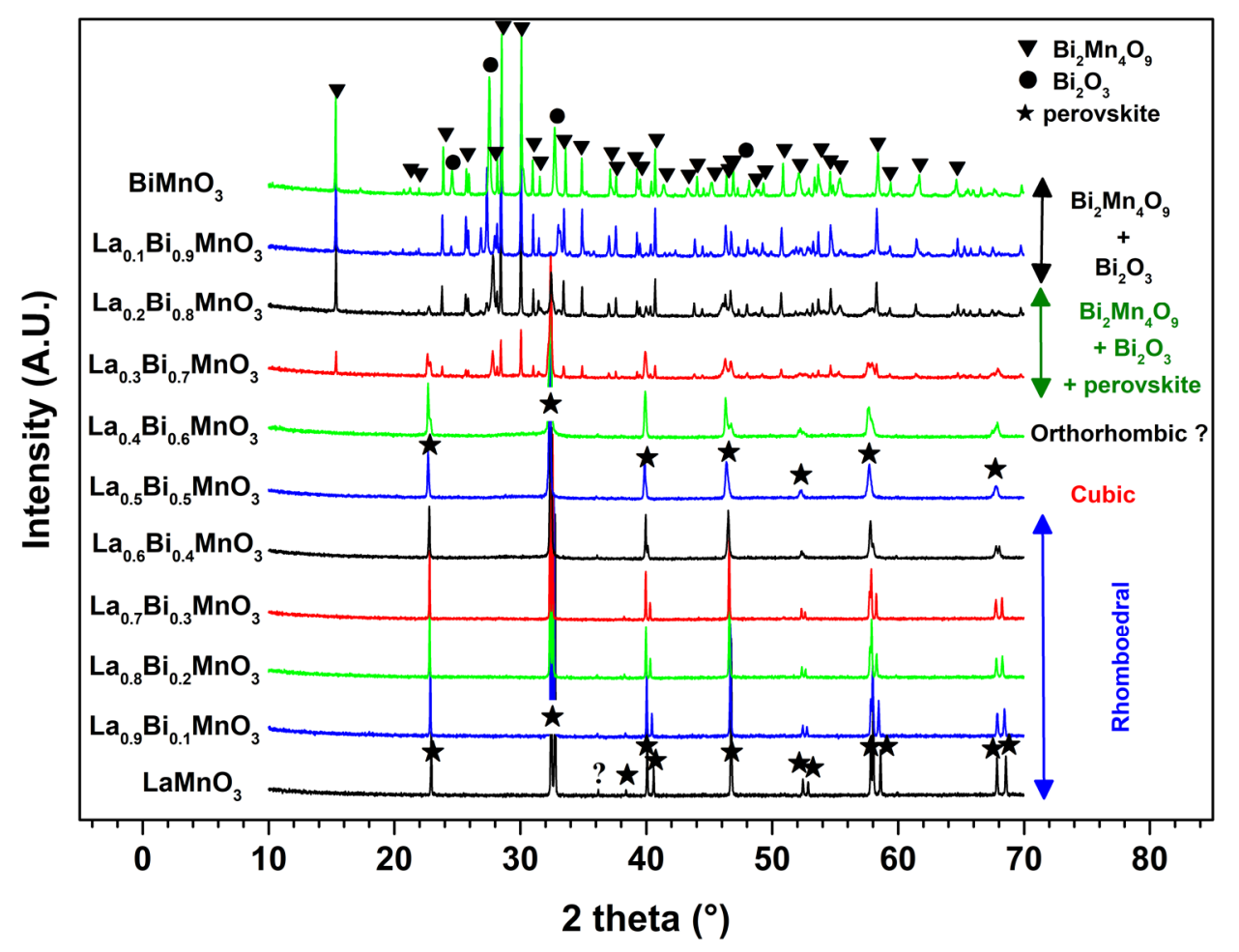

Figure 1: X-ray diffraction patterns for the $\mathrm{La}_{(1-\mathrm{x})} \mathrm{Bi}_{\mathrm{x}} \mathrm{MnO}_{3}$ system ( $\mathrm{x}=0$ to 1$)$

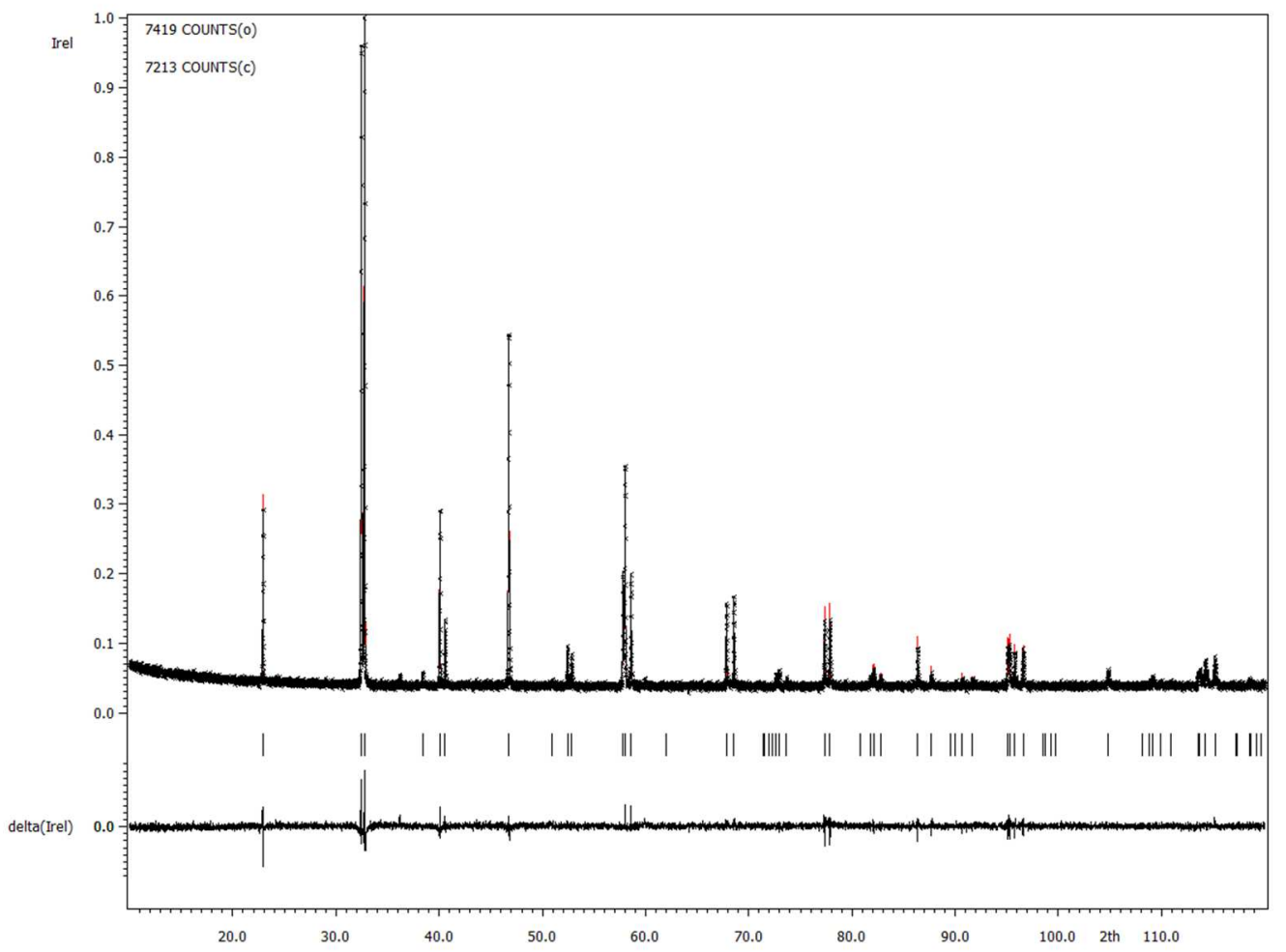

Figure2: Result of the refinement of $\mathrm{LaMnO}_{3}$ composition $(\mathrm{x}=0)$ using a rhombohedral $R \overline{3} c$ space group. 


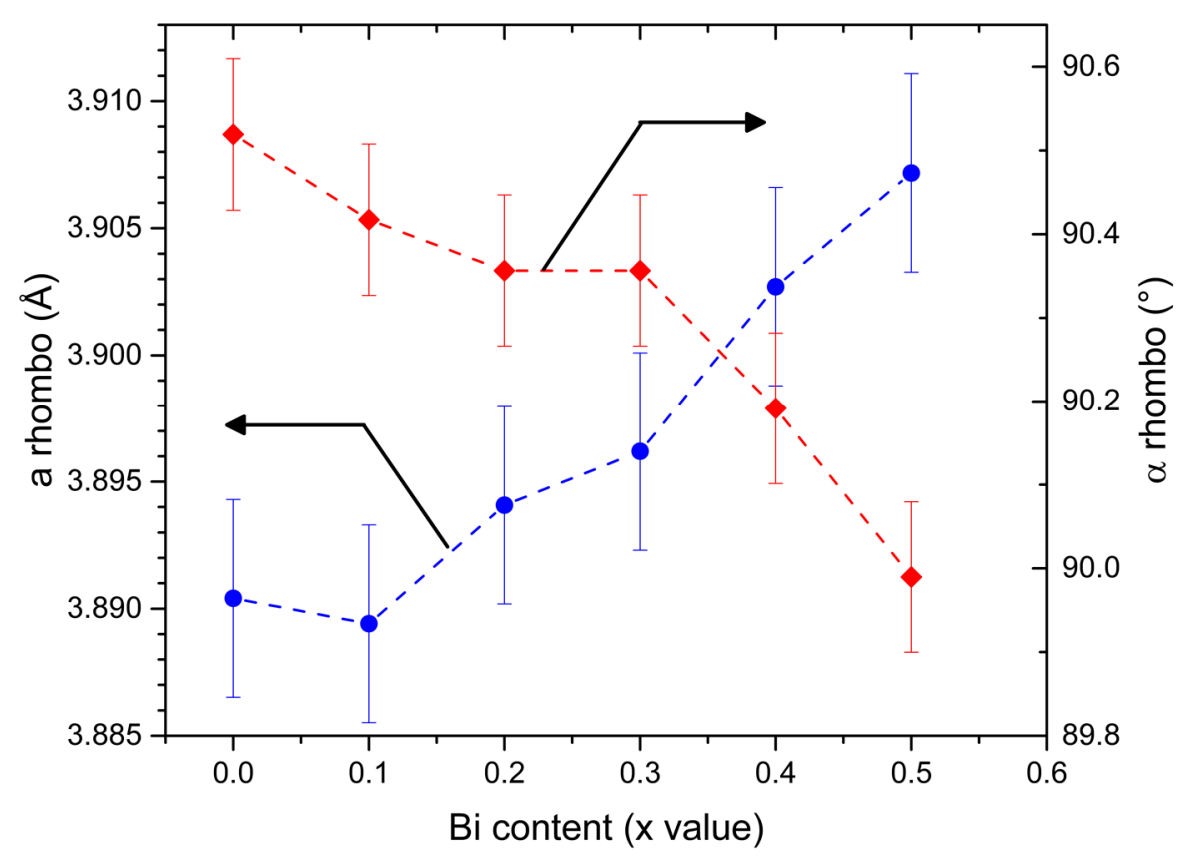

Figure 3: Evolution of the " $a$ " lattice parameter of the rhombohedral cell and of the " $\alpha$ " rhombohedral angle as a function of composition for the continuous part of the $\mathrm{La}(1-\mathrm{x}) \mathrm{Bi}_{\mathrm{x}} \mathrm{MnO}_{3}$ solid solution.
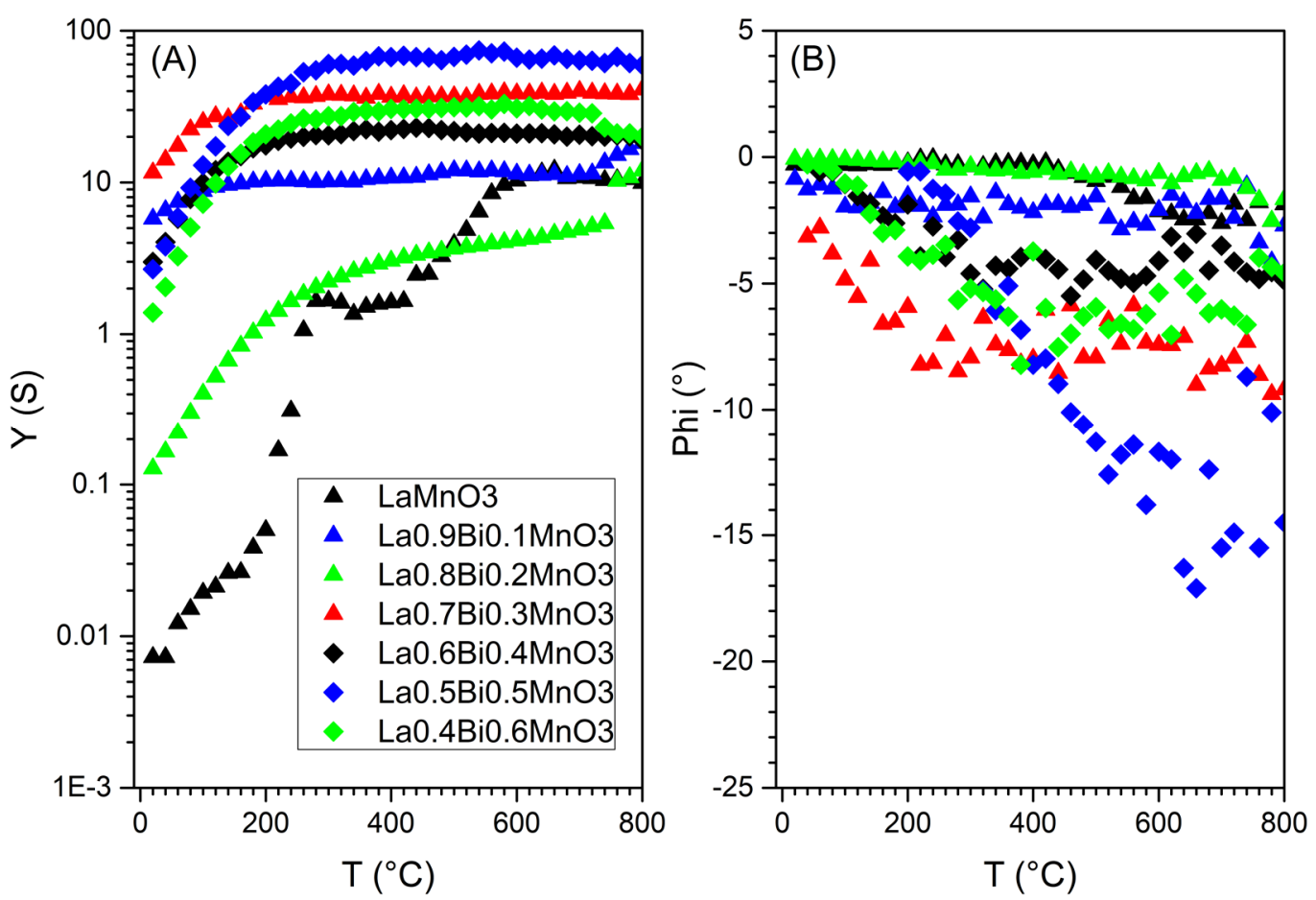

Figure 4: Results of AC measurements above room temperature: (A) Evolution of the admittance modulus $|\mathrm{Y}|$ and $(\mathrm{B})$ of the phase angle as a function of temperature for the single-phases perovskite compositions $(\mathrm{x}=0$ to $\mathrm{x}=0.6)$ of the $\mathrm{La}_{(1-\mathrm{x})} \mathrm{Bi}_{\mathrm{x}} \mathrm{MnO}_{3}$ solid solution. 


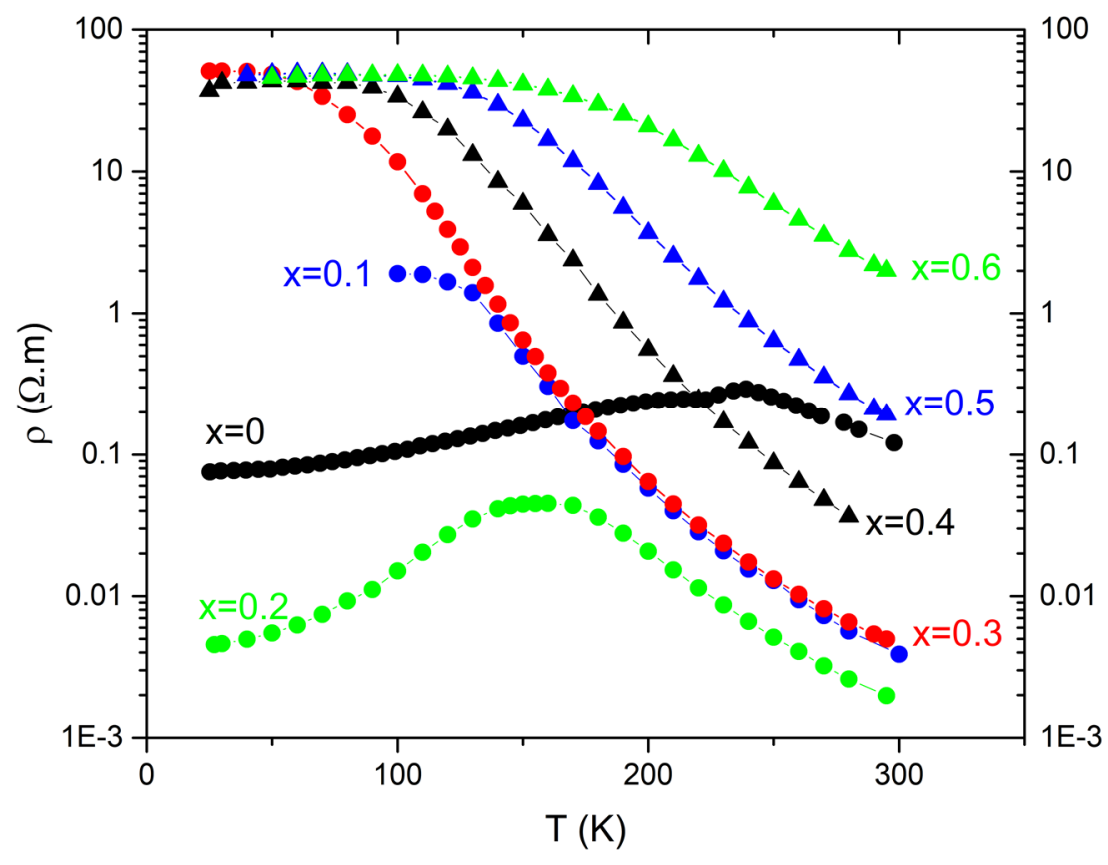

Figure 5: Evolution of the DC resistivity as a function of temperature for the single-phases perovskite compositions of the $\mathrm{La}_{(1-\mathrm{x})} \mathrm{Bi}_{\mathrm{x}} \mathrm{MnO}_{3}$ solid solution $(\mathrm{x}=0$ to $\mathrm{x}=0.6)$.

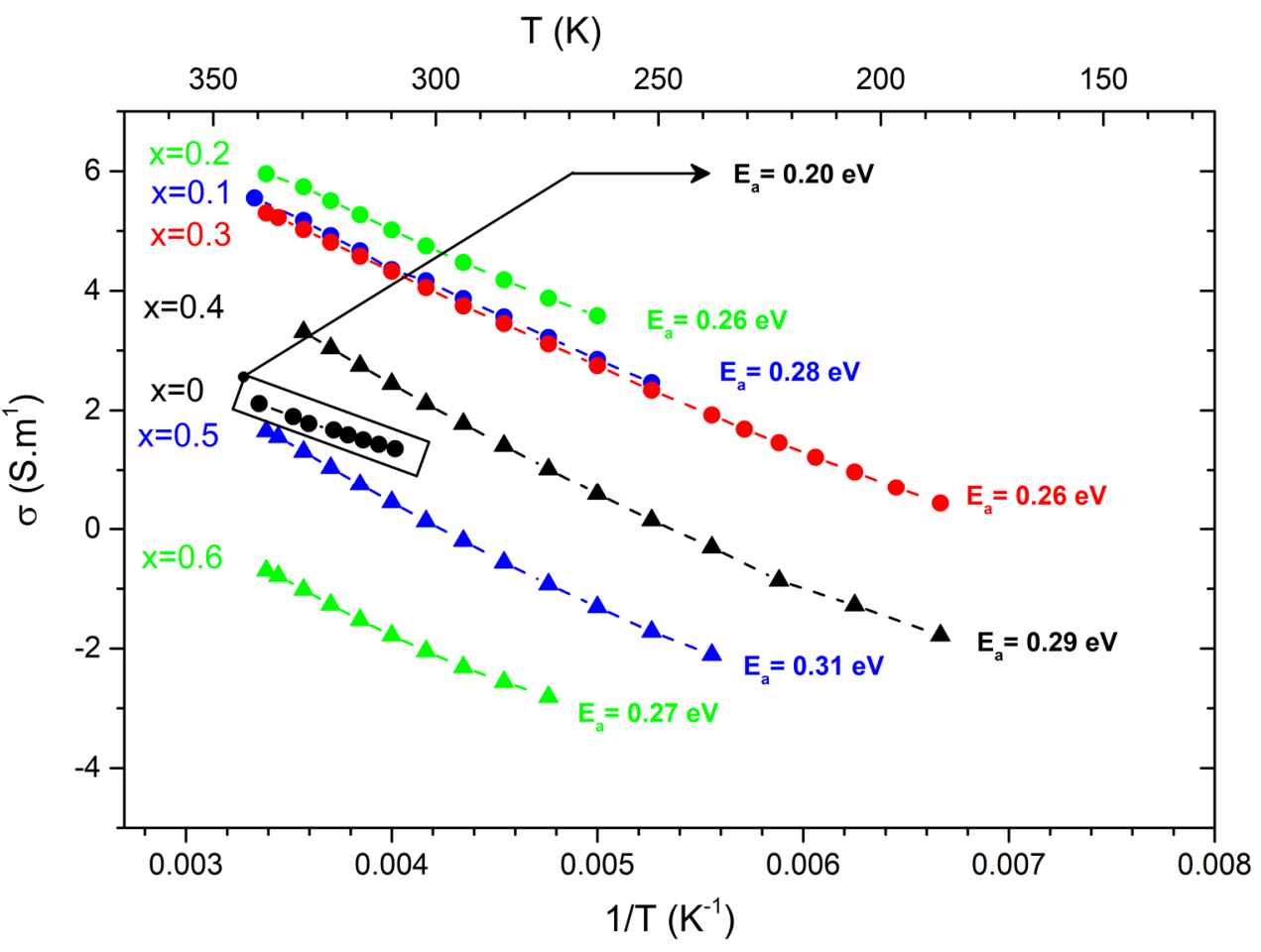

Figure 6: $\operatorname{Ln}(\sigma)$ as a function of $1 / \mathrm{T}$ extracted from the $\mathrm{DC}$ resistivity curves for the $\mathrm{La}_{(1-\mathrm{x})} \mathrm{Bi}_{\mathrm{x}} \mathrm{MnO}_{3}$ solid solution $(\mathrm{x}=0$ to $\mathrm{x}=0.6)$. 


\begin{tabular}{|l|c|c|c|c|c|c|}
\hline Composition & $\mathrm{LaMnO}_{3}$ & $\mathrm{La}_{0.9} \mathrm{Bi}_{0.1} \mathrm{MnO}_{3}$ & $\mathrm{La}_{0.8} \mathrm{Bi}_{0.2} \mathrm{MnO}_{3}$ & $\mathrm{La}_{0.7} \mathrm{Bi}_{0.3} \mathrm{MnO}_{3}$ & $\mathrm{La}_{0.6} \mathrm{Bi}_{0.4} \mathrm{MnO}_{3}$ & $\mathrm{La}_{0.5} \mathrm{Bi}_{0.5} \mathrm{MnO}_{3}$ \\
\hline \multicolumn{1}{|c|}{ Space group } & \multicolumn{7}{|c|}{$\mathrm{R} \overline{3} \mathrm{c}$} & \multicolumn{4}{l|}{0.5} \\
\hline \multicolumn{1}{|c|}{$\mathrm{X}$ value } & 0 & 0.1 & 0.2 & 0.3 & 0.4 & 5.5251 \\
\hline a hexa $(\AA)$ & 5.5267 & 5.5205 & 5.5239 & 5.5272 & 5.5285 & 13.5373 \\
\hline c hexa $(\AA)$ & 13.3541 & 13.3748 & 13.4064 & 13.4126 & 13.4741 & 3.9072 \\
\hline a rhombo $(\AA)$ & 3.8904 & 3.8894 & 3.8941 & 3.8962 & 3.9027 & 89.989 \\
\hline$\alpha$ rhombo $\left({ }^{\circ}\right)$ & 90.519 & 90.417 & 90.357 & 90.357 & 90.192 & 357.66 \\
\hline $\mathrm{V}\left(\AA^{3}\right)$ & 351.95 & 352.835 & 354.10 & 354.70 & 357.02 & 0.0192 \\
\hline $\mathrm{U}$ iso La/Bi & 0.0102 & 0.0120 & 0.0168 & 0.0211 & 0.0240 & 0.001 \\
\hline U iso Mn & 0.00682 & 0.001 & 0.001 & 0.001 & 0.001 & 0.55056 \\
\hline x oxygen & 0.55456 & 0.54885 & 0.54984 & 0.55273 & 0.54704 & 1.21 \\
\hline GOF & 1.25 & 1.18 & 1.16 & 1.15 & 1.16 & 7.16 \\
\hline Rp $(\%)$ & 5.35 & 5.03 & 5.82 & 6.32 & 6.6 & 8.93 \\
\hline WRp $(\%)$ & 6.83 & 6.29 & 7.27 & 7.9 & 8.25 & \\
\hline
\end{tabular}

Table 1: Structural parameters and reliability factors obtained after Rietveld refinement of $\mathrm{La}_{(1-}$ ${ }_{x)} \mathrm{Bi}_{\mathrm{x}} \mathrm{MnO}_{3} \mathrm{X}$-ray diffraction patterns

\begin{tabular}{|c|c|c|c|c|c|}
\hline & \multicolumn{5}{|c|}{ Sigma $\left(S . m^{-1}\right)$} \\
\hline$x$ & $100 \mathrm{~Hz}$ & $1 \mathrm{kHz}$ & $10 \mathrm{kHz}$ & $100 \mathrm{kHz}$ & $1 \mathrm{MHz}$ \\
\hline 0 & $6.5 \mathrm{E}-04$ & $6.5 \mathrm{E}-04$ & $6.5 \mathrm{E}-04$ & $6.4 \mathrm{E}-04$ & $6.4 \mathrm{E}-04$ \\
\hline 0.1 & $4.0 \mathrm{E}-01$ & $4.0 \mathrm{E}-01$ & $3.9 \mathrm{E}-01$ & $2.4 \mathrm{E}-01$ & $6.6 \mathrm{E}-03$ \\
\hline 0.2 & $9.8 \mathrm{E}-03$ & $9.8 \mathrm{E}-03$ & $9.8 \mathrm{E}-03$ & $9.8 \mathrm{E}-03$ & $9.4 \mathrm{E}-03$ \\
\hline 0.3 & $9.0 \mathrm{E}-01$ & $8.9 \mathrm{E}-01$ & $8.4 \mathrm{E}-01$ & $4.7 \mathrm{E}-01$ & $5.6 \mathrm{E}-02$ \\
\hline 0.4 & $1.9 \mathrm{E}-01$ & $1.9 \mathrm{E}-01$ & $1.9 \mathrm{E}-01$ & $1.6 \mathrm{E}-01$ & $1.1 \mathrm{E}-02$ \\
\hline 0.5 & $2.0 \mathrm{E}-01$ & $2.0 \mathrm{E}-01$ & $1.9 \mathrm{E}-01$ & $1.7 \mathrm{E}-01$ & $1.4 \mathrm{E}-02$ \\
\hline 0.6 & $9.4 \mathrm{E}-02$ & $9.3 \mathrm{E}-02$ & $9.3 \mathrm{E}-02$ & $9.0 \mathrm{E}-02$ & $2.0 \mathrm{E}-02$ \\
\hline 0.7 & $8.7 \mathrm{E}-07$ & $1.0 \mathrm{E}-06$ & $1.8 \mathrm{E}-06$ & $5.0 \mathrm{E}-06$ & $1.4 \mathrm{E}-05$ \\
\hline 0.8 & $1.0 \mathrm{E}-07$ & $3.4 \mathrm{E}-07$ & $1.1 \mathrm{E}-06$ & $3.0 \mathrm{E}-06$ & $1.6 \mathrm{E}-05$ \\
\hline 0.9 & $2.7 \mathrm{E}-08$ & $9.9 \mathrm{E}-08$ & $3.9 \mathrm{E}-07$ & $8.3 \mathrm{E}-07$ & $1.7 \mathrm{E}-06$ \\
\hline 1 & $1.0 \mathrm{E}-07$ & $1.9 \mathrm{E}-07$ & $4.6 \mathrm{E}-07$ & $9.4 \mathrm{E}-07$ & $1.8 \mathrm{E}-06$ \\
\hline
\end{tabular}

Table 2: conductivity values $\left(\sigma_{\mathrm{AC}}\right)$ at room temperature $\left(20^{\circ} \mathrm{C}\right)$ extracted from the admittance measurements 